\title{
Oxygen control and improved denitrification efficiency by dosing ferrous ions in the anoxic reactor
}

\section{Paolo Viotti, Maria Cristina Collivignarelli, Elisa Martorelli \& Massimo Raboni}

To cite this article: Paolo Viotti, Maria Cristina Collivignarelli, Elisa Martorelli \& Massimo Raboni (2015): Oxygen control and improved denitrification efficiency by dosing ferrous ions in the anoxic reactor, Desalination and Water Treatment, DOI: 10.1080/19443994.2015.1089200

To link to this article: http://dx.doi.org/10.1080/19443994.2015.1089200

曲 Published online: 17 Sep 2015.

Submit your article to this journal

Џ Article views: 8

Q View related articles $₫$

View Crossmark data $\asymp$ 


\title{
Oxygen control and improved denitrification efficiency by dosing ferrous ions in the anoxic reactor
}

\author{
Paolo Viotti ${ }^{\mathrm{a}, *}$, Maria Cristina Collivignarelli ${ }^{\mathrm{b}}$, Elisa Martorelli ${ }^{\mathrm{a}}$, Massimo Raboni ${ }^{\mathrm{c}}$ \\ ${ }^{a}$ Department of Civil and Environmental Engineering, University of Roma "La Sapienza", Via Eudossiana 18, I-00184 Rome, Italy, \\ Tel.+39 3358369416; emails: paolo.viotti@uniroma1.it (P. Viotti), elisa.martorelli@uniroma1.it (E. Martorelli) \\ ${ }^{b}$ Department of Civil Engineering and Architecture, University of Pavia, Via Ferrata 1, I-27100 Pavia, Italy, Tel. +39 0382 985312; \\ email: moristina.collivignarelli@unipv.it \\ 'School of Industrial Engineering, University LIUC-Cattaneo, Corso Matteotti 22, I-21053 Castellanza (VA), Italy, \\ Tel.+393283246231; email: mraboni@liuc.it
}

Received 17 June 2015; Accepted 26 August 2015

\begin{abstract}
Small concentrations of dissolved oxygen (DO) in the range $0.2-0.4 \mathrm{mg} \mathrm{L}^{-1}$ normally are present in biological pre-denitrification reactors. This situation causes adverse effects on denitrification rate and, consequently, on the process efficiency. The results presented show the possibility to control the DO in the anoxic reactor by dosing ferrous Fe(II) ions. The experiments were carried out on both batch samples and a pilot plant and proved that oxidation of $\mathrm{Fe}(\mathrm{II})$ to $\mathrm{Fe}$ (III) is very efficient in the DO control. Moreover, Fe(III) reacts with phosphorus which precipitates as ferric orthophosphate. A dose of $6 \mathrm{mgFe}^{2+} \mathrm{L}^{-1}$ decreased the mean DO concentration from 0.45 to $0.28 \mathrm{mg} \mathrm{L}^{-1}$; as a consequence, the denitrification efficiency $\left(\eta_{\mathrm{DEN}}\right)$ increased from about $65-77 \%$. $\eta_{\mathrm{DEN}}$ reached up to $89 \%$ with $9 \mathrm{mgFe}^{2+} \mathrm{L}^{-1}$ (50\% over the stoichiometric for phosphorus removal) thanks to an average DO concentration of $0.08 \mathrm{mgO}_{2} \mathrm{~L}^{-1}$ in the denitrification stage. The results also highlighted the strong influence of DO (and consequently the dosage of $\mathrm{Fe}^{2+}$ ) on the specific denitrification rate suggesting to maintain DO concentration in the pre-denitrification reactors lower than $0.2 \mathrm{mg} \mathrm{L}^{-1}$ in order to achieve high operation efficiencies.

Keywords: Biological nitrogen removal; Combined nitrogen and phosphorus removal; Ferrous iron dosing; Dissolved oxygen control; Wastewater treatment plant design
\end{abstract}

\section{Introduction}

The design of the biological anoxic pre-denitrification reactors is normally made on the basis of the denitrification rate $\left(r_{\text {DEN }}\right)$, which is defined as the $\mathrm{NO}_{3}-\mathrm{N}$ removal by dissimilation assuming a zeroorder kinetics (in relation to both $\mathrm{NO}_{3}-\mathrm{N}$ and organic

${ }^{*}$ Corresponding author. substrate) and considering the significant effect of the temperature [1-11].

Biological denitrification efficiency depends on many factors, such as the retention time, the organic load, and the mixed liquor (ML) recycle [1,4,11,12]. In addition, $\mathrm{DO}\left(\mathrm{DO}_{\mathrm{DEN}}\right)$ control is known to be a very important factor in the denitrification stage.

Average daily concentrations of $\mathrm{DO}_{\mathrm{DEN}}$ in real-scale plants are in the range $0.2-0.4 \mathrm{mg} \mathrm{L}^{-1}$, with

1944-3994/1944-3986 ㄷ 2015 Balaban Desalination Publications. All rights reserved. 
higher values during the day, especially in small sewage treatment plants $[13,14]$. The inhibitory effect due to the DO concentration found in the anoxic reactors is the result of two opposing factors: on the one hand, the intake of oxygen loads associated with the raw sewage, the sludge recycle and, mainly, the ML recycle; on the other hand, the oxygen consumption determined by the heterotrophic bacteria activity [15].

The effect of dissolved oxygen (DO) on the kinetics of the denitrification process was postulated in 1975 by US-EPA [1] and subsequently highlighted by inserting the inhibition factor $K_{0}^{\prime} /\left(K_{0}^{\prime}+\mathrm{DO}\right)$ in the expression [16,17]:

$$
\begin{aligned}
r_{\mathrm{DEN}}= & \left(\frac{1-1.42 Y}{2.86}\right) \cdot\left(\frac{K \cdot S \cdot X}{K_{\mathrm{s}}+S}\right) \cdot\left(\frac{\mathrm{NO}_{3}-\mathrm{N}}{K_{\mathrm{N}}+\mathrm{NO}_{3}-\mathrm{N}}\right) \\
& \cdot\left(\frac{K_{0}^{\prime}}{K_{0}^{\prime}+\mathrm{DO}_{\mathrm{DEN}}}\right) \cdot \eta
\end{aligned}
$$

where $Y$ is the heterotrophic bacteria synthesis yield (mgVSS mg substrate consumed ${ }^{-1}$ ); $K$ is the maximum specific rate of substrate utilization $\left(\mathrm{h}^{-1}\right) ; X$ is the biomass concentration $\left(\mathrm{mgMLVSS} \mathrm{L}^{-1}\right)$; $S$ is the soluble degradable substrate concentration $\left(\mathrm{mg} \mathrm{L}^{-1}\right) ; K_{\mathrm{s}}$ is the substrate utilization half-velocity coefficient $\left(\mathrm{mg} \mathrm{L}^{-1}\right)$; $\mathrm{NO}_{3}-\mathrm{N}$ is the nitrate concentration as $\mathrm{N}\left(\mathrm{mg} \mathrm{L}^{-1}\right) ; K_{\mathrm{N}}$ is the nitrate half-velocity coefficient $\left(\mathrm{mg} \mathrm{L}^{-1}\right) ; K_{0}^{\prime}$ is the DO inhibition constant for nitrate reduction $\left(\mathrm{mgO}_{2} \mathrm{~L}^{-1}\right) ; \eta$ is the fraction of heterotrophic bacteria that use nitrate in lieu of oxygen (dimensionless).

Different studies highlighted the inhibitory effect of DO on denitrification efficiency [18-24]. The DO inhibition on the $r_{\text {DEN }}$ has been observed at $0.20 \mathrm{mgO}_{2} \mathrm{~L}^{-1}$ [18], but on a theoretical basis, the mere presence of $0.2 \mathrm{mgO}_{2} \mathrm{~L}^{-1}$ determines the drop of $r_{\text {DEN }}$ up to $40 \%$ compared to the maximum values obtained in the absence of inhibition [12]. Therefore, $K_{0}^{\prime}$ is considered variable in a wide range $\left(0.02-0.2 \mathrm{mgO}_{2} \mathrm{~L}^{-1}\right)$, which depends on both the floc size and structure [12].

For practical calculation of the denitrification reactor volume, a semi-empirical relation was proposed [12,25-27]. It correlates the specific denitrification rate $(\mathrm{SDNR})$ at $20^{\circ} \mathrm{C}\left(\mathrm{SDNR}_{20}{ }^{\circ} \mathrm{C}, \mathrm{gNO}_{3}-\mathrm{N} \mathrm{gMLVSS}^{-1} \mathrm{~d}^{-1}\right)$ to the sludge loading only referred to the denitrification reactor:

$\mathrm{SDNR}_{20^{\circ} \mathrm{C}}=0.03 \cdot \mathrm{F}: \mathrm{M}_{\mathrm{DEN}}+0.029$

where $F: M_{D E N}$ is the sludge loading in the denitrification stage $\left(\mathrm{gBOD}_{5}\right.$ applied gMLVSS $\left.{ }^{-1} \mathrm{~d}^{-1}\right)$. The values of SDNR observed in the pre-anoxic reactors of full scale plants range from 0.04 to $0.42 \mathrm{gNO}_{3}-\mathrm{N}$ gMLVSS $^{-1} \mathrm{~d}^{-1}[17,24,26]$. More recently, Raboni et al. [28] highlighted the strong dependence of SDNR in the sewage pre-denitrification from both DO and $\mathrm{F}: \mathrm{M}_{\mathrm{DEN}}$ :

$$
\begin{aligned}
\mathrm{SDNR}_{20^{\circ} \mathrm{C}}= & 0.0864\left(\frac{K_{0}^{\prime}}{K_{0}^{\prime}+\mathrm{DO}}\right)+0.05 \mathrm{~F}: \mathrm{M}_{\mathrm{DEN}} \cdot \eta_{\mathrm{BOD}} \\
& \cdot\left(\frac{\mathrm{DO}}{0.2+\mathrm{DO}}\right)
\end{aligned}
$$

where $K_{0}^{\prime}=0.18 \mathrm{mgO}_{2} \mathrm{~L}^{-1}$ is the DO inhibition constant; $\eta_{\mathrm{BOD}}$ is the BOD removal efficiency, which depends on $\mathrm{F}: \mathrm{M}_{\mathrm{DEN}}\left(\eta_{\mathrm{BOD}}=0.90\right.$ for $\mathrm{F}: \mathrm{M}_{\mathrm{DEN}}=0.4 \mathrm{~kg}$ $\mathrm{BOD}_{5} \mathrm{kgMLVSS}^{-1} \mathrm{~d}^{-1} ; \eta_{\mathrm{BOD}}=0.95$ for $\mathrm{F}: \mathrm{M}_{\mathrm{DEN}}=0.2 \mathrm{~kg}$ $\mathrm{BOD}_{5} \mathrm{~kg} \mathrm{MLVSS}^{-1} \mathrm{~d}^{-1}$ ).

Assessed the great dependence of the $r_{\text {DEN }}$ from $\mathrm{DO}$, the paper shows the possibility of reducing the DO concentration through the dosage of ferrous Fe(II) ions in the anoxic reactor. The oxidation of $\mathrm{Fe}(\mathrm{II})$ with oxygen in an aqueous environment is carried out according to the following reaction:

$4 \mathrm{Fe}^{2+}+\mathrm{O}_{2}+8 \mathrm{OH}^{-}+2 \mathrm{H}_{2} \mathrm{O} \rightarrow 4 \mathrm{Fe}(\mathrm{OH})_{3} \downarrow$

The kinetics of Fe(II) oxidation has been studied extensively [29-33]. It depends on several factors including temperature, $\mathrm{pH}$, concentrations of $\mathrm{Fe}(\mathrm{II})$ and $\mathrm{DO}$. Generally, the recognized kinetic expression is the following:

$\frac{\mathrm{d}\left[\mathrm{Fe}^{2+}\right]}{\mathrm{d} t}=K_{\mathrm{Fe}} \cdot\left[\mathrm{Fe}^{2+}\right] \cdot\left[\mathrm{OH}^{-}\right]^{2} \cdot \mathrm{pO}_{2}$

where $\mathrm{pO}_{2}$ is the partial pressure of oxygen; $\left[\mathrm{Fe}^{2+}\right]$ and $\left[\mathrm{OH}^{-}\right]$are the molar concentrations of bivalent iron and hydroxyl ion; $K_{\mathrm{Fe}}$ is the kinetic constant with values typically ranging from 1 to $6 \mathrm{E}+13 \mathrm{M}^{-2} \mathrm{~atm}^{-1} \mathrm{~min}^{-1}$ [34].

The kinetic equation shows the strong influence of $\mathrm{pH}$ on the oxidation rate. Applying Eq. (5) with a DO concentration of $1 \mathrm{mgO}_{2} \mathrm{~L}^{-1}$, Davison and Seed [32] calculated a half time for $\mathrm{Fe}^{2+}$ oxidation corresponding to $30 \mathrm{~min}$ with a $\mathrm{pH}$ value of 7.4 and $100 \mathrm{~min}$ at $\mathrm{pH}$ equal to $7.0\left(K_{\mathrm{Fe}}=2 \mathrm{E}+13 \mathrm{M}^{-2} \mathrm{~atm}^{-1} \mathrm{~min}^{-1}\right)$.

It is worth to note that a biological reduction of both nitrate and nitrite was found to take place in the activated sludge concomitantly with the oxidation of $\mathrm{Fe}(\mathrm{II})$ ions [35]. This process seems of potential interest for activated sludge processes, but many aspects should be studied with more detail.

The paper shows the results of batch tests carried out on ML samples collected at the initial stage of the 
denitrification reactor in order to verify the influence of $\mathrm{Fe}$ (II) dosage on the DO concentration. The effects of $\mathrm{Fe}(\mathrm{II})$ on the denitrification process have been also tested on a pilot plant in order to define the optimal DO concentration for improving both the SDNR and the denitrification efficiency.

\section{Materials and methods}

\subsection{Preliminary batch tests}

Batch tests were carried out on samples of ML in order to measure the DO consumption rate. The samples were collected from a pilot plant described in section 2.2. Each test was carried out on four samples (volume: $1.0 \mathrm{~L}$ ):

(1) Sample $a$ : raw ML collected at the initial stage of the anoxic pre-denitrification reactor $\left(\mathrm{ML}_{\mathrm{DEN}}\right)$.

(2) Sample $b$ : $\mathrm{ML}_{\mathrm{DEN}}$ with $\mathrm{Fe}^{2+}(0 \%$ over the stoichiometric dosage for $\mathrm{P}_{\text {tot }}$ removal).

(3) Sample c: $\mathrm{ML}_{\mathrm{DEN}}$ with $\mathrm{Fe}^{2+}(50 \%$ over the stoichiometric dosage for $\mathrm{P}_{\text {tot }}$ removal).

(4) Sample $d$ : ML recycle.

Samples were mixed slowly in order to avoid solubilization of atmospheric oxygen. Twenty batch tests were carried out with ML at different initial DO concentration. The purpose of the preliminary investigation was to compare the DO consumption rate due to the bacterial respiration in presence of:

(1) Endogenous carbon only (sample $d$ ).

(2) Endogenous carbon and BOD (sample $a$ ).

(3) Endogenous carbon and BOD in presence of the chemical reduction due to $\mathrm{Fe}^{2+}$ addition (sample $b, c$ ).

\subsection{Pilot plant experience}

\subsubsection{Pilot plant description}

An activated sludge pilot plant (Fig. 1) with a biological anoxic pre-denitrification tank (DEN), an oxidation-nitrification stage (OX-NIT) and a final sedimentation (SED) was used for the full scale tests. The pilot plant was fed by pre-treated (screening and aerated grit chamber) sewage from a town of 50,000 inhabitants.

The main features of the pilot plant were as follows:

(1) DEN: volume $10 \mathrm{~m}^{3}$; liquid height $1.8 \mathrm{~m}$; mixing: four slow vertical axis mixers (power input: $11 \mathrm{~W} \mathrm{~m}^{-3}$ ).
(2) OX-NIT: volume $20 \mathrm{~m}^{3}$; liquid height $1.8 \mathrm{~m}$; aeration: micro-bubble aeration system.

(3) SED: diameter $2 \mathrm{~m}$; volume $6 \mathrm{~m}^{3}$.

(4) Sewage flow rate: $Q_{\text {sew }}=2 \mathrm{~m}^{3} \mathrm{~h}^{-1}$.

(5) ML recycle flow rate: $Q_{\mathrm{ML}}=6 \mathrm{~m}^{3} \mathrm{~h}^{-1}$.

(6) Sludge recycle flow rate: $Q_{\mathrm{SR}}=Q_{\text {sew }}$.

\subsubsection{Pilot plant operating conditions and testing methods}

The pilot plant operating conditions were set in order to verify the impact of $\mathrm{Fe}^{2+}$ dosage on the: (i) average DO concentration in DEN (average $\mathrm{DO}_{\mathrm{DEN}}$, measured as the arithmetic mean of all the DO measurements in DEN) and, consequently, on the denitrification performance expressed as $\mathrm{N}-\mathrm{NO}_{3}$ removal efficiency $\left(\eta_{\text {DEN }}\right)$; (ii) SDNR, calculated as follows:

$\mathrm{SDNR}=\frac{Q \cdot \Delta \mathrm{NO}_{3}-\mathrm{N}}{V_{\mathrm{DEN}} \cdot X}$

where $Q$ is the sewage flow rate $\left(\mathrm{m}^{3} \mathrm{~d}^{-1}\right), \Delta \mathrm{NO}_{3}-\mathrm{N}$ is the removed nitrogen, as nitrate, per unit of volume $\left(\mathrm{gNO}_{3}-\mathrm{N} \mathrm{m}^{-3}\right) ; V_{\mathrm{DEN}}$ is the denitrification reactor volume $\left(\mathrm{m}^{3}\right) ; X$ is the biomass concentration.

The pilot plant ran for a continuous period of six months. In this period, the F: $\mathrm{M}_{\mathrm{DEN}}$ was maintained within the range $0.2-0.4 \mathrm{~kg} \quad \mathrm{BOD}_{5} \mathrm{kgMLVSS}^{-1} \mathrm{~d}^{-1}$ (average value: $0.3 \mathrm{~kg}$ BOD $_{5} \mathrm{kgMLVSS}^{-1} \mathrm{~d}^{-1}$ ) with an average MLVSS concentration kept at $2.0 \mathrm{~g} \mathrm{~L}^{-1}$. DO in OX-NIT was kept in the range $2.0-3.5 \mathrm{mgO}_{2} \mathrm{~L}^{-1}$.

After $90 \mathrm{~d}$, the $\mathrm{Fe}^{2+}$ dosing (as $\mathrm{FeSO}_{4}$ solution) in the first denitrification tank started. Three different concentrations were used, each for a period of $30 \mathrm{~d}$ :

(1) $6.0 \mathrm{mgFe}^{2+} \mathrm{L}^{-1}$ (0\% over the stoichiometric for $P_{\text {tot }}$ removal).

(2) $7.5 \mathrm{mgFe}^{2+} \mathrm{L}^{-1}$ (25\% over the stoichiometric for $P_{\text {tot }}$ removal).

(3) $9.0 \mathrm{mgFe}^{2+} \mathrm{L}^{-1}$ (50\% over the stoichiometric for $\mathrm{P}_{\text {tot }}$ removal).

During the experience, the following analytical parameters were measured:

(1) $\mathrm{BOD}_{5}, \mathrm{COD}, \mathrm{TN}, \mathrm{NO}_{3}-\mathrm{N}, \mathrm{P}_{\text {tot }}$ and suspended solids concentrations in the pre-treated sewage entering the pilot plant and in the pilot plant effluent (an automatic daily average sampler was used).

(2) $\mathrm{TN}$ and $\mathrm{NO}_{3}-\mathrm{N}$ concentrations entering the DEN and in the filtered samples of the inlet to OX-NIT (automatic daily average samplings). 


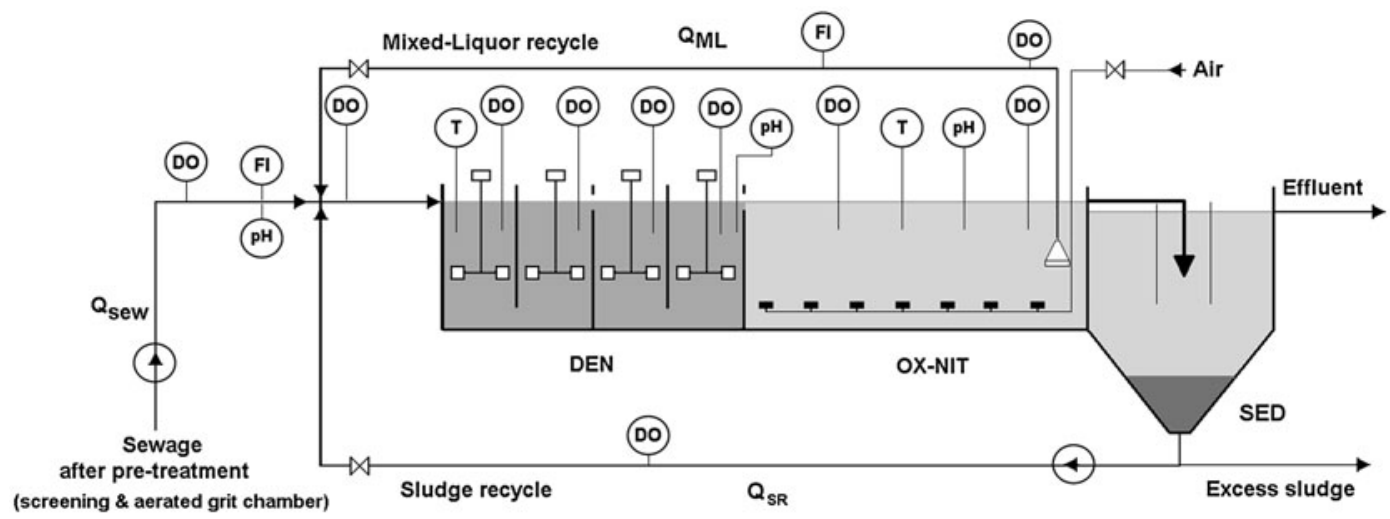

Fig. 1. Scheme of the pilot plant.

(3) MLVSS and MLSS concentrations in DEN and OX-NIT (manual sampling).

(4) Temperature in DEN and OX-NIT (fixed probes; accuracy: $\pm 0.05^{\circ} \mathrm{C}$ ), as shown in Fig. 1 .

(5) $\mathrm{DO}$ concentration in ten measure points (Fig. 1) by means of continuous sampling fixed probes (accuracy: $\pm 0.01 \mathrm{mgO}_{2} \mathrm{~L}^{-1}$; automatic calibration; temperature compensation).

(6) $\mathrm{pH}$ at three measure points (Fig. 1) with continuous sampling fixed probes (accuracy: $\pm 0.05)$.

Sampling and analysis were carried out in compliance with official standard methods [36].

\section{Results and discussion}

\subsection{Mean quality of the raw sewage and the treated effluent}

Table 1 shows the quality of both the raw sewage and the treated effluent collected during the first $90 \mathrm{~d}$ (no $\mathrm{Fe}^{2+}$ addition).

The results indicate a "low strength" sewage. The average efficiency of the plant is 70.8, 90.0, 64.3 and $22 \%$ for $\mathrm{COD}, \mathrm{BOD}_{5}, \mathrm{TN}$ and $\mathrm{P}_{\text {tot }}$, respectively. The removal efficiency of $\mathrm{TN}$ is indeed quite poor compared to expectations. This result is largely determined by the excessive presence of DO in DEN (average daily value: $0.49 \mathrm{mgO}_{2} \mathrm{~L}^{-1}$ ) mainly due to the heavy fluctuations of the sewage quality as shown in [13].

\subsection{Preliminary batch tests}

Fig. 2 shows two representative results of the investigation carried out on batch tests of $M L_{D E N}$ and

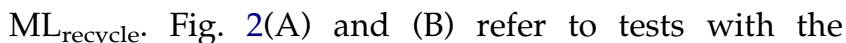
lowest and highest initial DO concentration, respectively.

The initial values measured at the first stage of DEN (samples $a, b$ and $c$ ) show a strong variability of DO concentration of the ML at the inlet of the denitrification stage (range: $0.97-0.26 \mathrm{mgO}_{2} \mathrm{~L}^{-1}$ ). This is surely due to the high DO content found in the $\mathrm{ML}_{\text {recycle }}$ coming from the oxidation stage (samples $d$; DO range: $2.1-3.4 \mathrm{mgO}_{2} \mathrm{~L}^{-1}$ ).

Analysing the DO behaviour as a function of time, the curves of the two graphs show similar trends. The comparison between the DO consumption rate of $\mathrm{ML}_{\mathrm{DEN}}$ (samples $a$ ) and $\mathrm{ML}_{\text {recycle }}$ (samples $d$ ) highlights the influence of BOD content, that is negligible in the $\mathrm{ML}_{\text {recycle }}$ because of the biological oxidation, and on the contrary high in $M L_{D E N}$, being this is a combination of raw sewage, ML recycle and sludge recycle. Focusing on the effects of $\mathrm{Fe}^{2+}$ dosing, the samples $a$ show the DO consumption due only to BOD and endogenous carbon while the samples $b$ and $c$ contain the additional effect of $\mathrm{Fe}^{2+}$. Using the stoichiometric doses of $\mathrm{Fe}^{2+}$ for $\mathrm{P}_{\text {tot }}$ removal (samples b), with a contact times of only 5-30 min (depending on the initial DO concentrations), it was possible to bring the DO concentration below $0.05 \mathrm{mgO}_{2} \mathrm{~L}^{-1}$. Better results (2-12 $\mathrm{min}$ ) were obtained with a significant dosage of $\mathrm{Fe}^{2+}\left(50 \%\right.$ over the stoichiometric for $\mathrm{P}_{\text {tot }}$ removal; samples $c$ ). These results are considerably better than those obtained with no $\mathrm{Fe}^{2+}$ addition (11-50 min; samples $a$ ).

\subsection{Pilot plant}

Fig. 3 shows the performance of biological denitrification as function of the DO average concentration in DEN during the whole experimentation period. 
Table 1

Quality of the raw sewage and the treated effluent (mean daily values and standard deviation on 60 samples of pre-treated sewage and treated effluent, respectively)

\begin{tabular}{llll}
\hline & & Daily values & \\
\cline { 3 - 4 } Parameter & Unit of measurement & Mean $(\mathrm{m})$ & Standard deviation (SD) \\
\hline COD in & $\mathrm{mg} \mathrm{L}^{-1}$ & 276.5 & 61.1 \\
COD out & $\mathrm{mg} \mathrm{L}^{-1}$ & 80.5 & 16.9 \\
BOD $_{5}$ in & $\mathrm{mg} \mathrm{L}^{-1}$ & 129.0 & 44.0 \\
BOD $_{5}$ out & $\mathrm{mg} \mathrm{L}^{-1}$ & 12.9 & 2.1 \\
$\mathrm{SS}$ in & $\mathrm{mg} \mathrm{L}^{-1}$ & 148.0 & 49.0 \\
$\mathrm{SS}$ out & $\mathrm{mg} \mathrm{L}^{-1}$ & 18.5 & 4.1 \\
$\mathrm{TN}$ TKN in & $\mathrm{mg} \mathrm{L}^{-1}$ & 28.6 & 4.9 \\
TN out & $\mathrm{mg} \mathrm{L}^{-1}$ & 10.2 & 2.8 \\
$P_{\text {tot }}$ in & $\mathrm{mg} \mathrm{L}^{-1}$ & 5.0 & 1.5 \\
$P_{\text {tot }}$ out & $\mathrm{mg} \mathrm{L}^{-1}$ & 3.9 & 0.8 \\
\hline
\end{tabular}

${ }^{\mathrm{a}} \mathrm{All} \mathrm{NO}_{3}-\mathrm{N}$ (TKN in the effluent always less than $0.5 \mathrm{mg} \mathrm{L}^{-1}$ ).
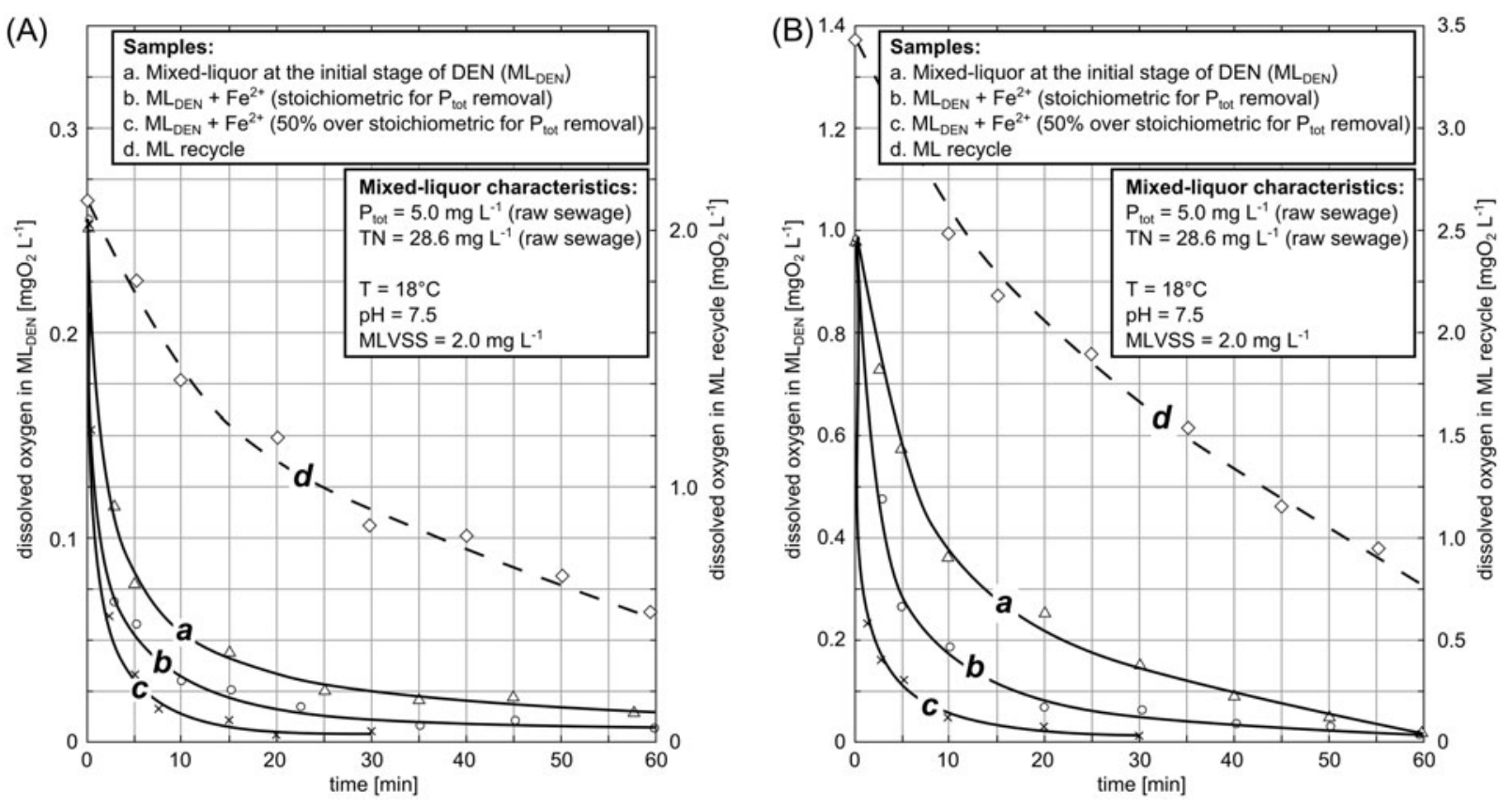

Fig. 2. Trend of DO in the preliminary batch tests carried out on ML samples collected simultaneously in the initial stage of denitrification $\left(\mathrm{ML}_{\mathrm{DEN}}\right)$ and in the mixed liquor recycle $\left(\mathrm{ML}_{\text {recycle }}\right)$ : cases with the lowest $(\mathrm{A})$ and the highest $(\mathrm{B})$ initial DO content.

As stated above, during the first period (no $\mathrm{Fe}^{2+}$ dosage), high concentrations of DO (mean: $0.49 \mathrm{mgO}_{2} \mathrm{~L}^{-1}$ ) negatively affected the achievement of good denitrification removal efficiencies (mean: 62\%). Another reason of such poor performance was the great variability in average $\mathrm{DO}_{\mathrm{DEN}}$ which was reflected by $\eta_{\text {DEN }}\left(0.34-0.64 \mathrm{mgO}_{2} \mathrm{~L}^{-1}\right.$ with performance of $72-53 \%$, respectively).
The $\mathrm{Fe}^{2+}$ dosing reduced $\mathrm{DO}_{\mathrm{DEN}}$ concentrations up to $0.08 \mathrm{mgO}_{2} \mathrm{~L}^{-1}$ smoothing the variability of the denitrification performances: average removal efficiencies of 73,84 and $89 \%$ with 0,25 and $50 \%$ over the stoichiometric dosage for $P_{\text {tot }}$ removal, were obtained, respectively. It is worth to note that a stoichiometric dosage of $\mathrm{Fe}^{2+}$ for $\mathrm{P}_{\text {tot }}$ removal reduced average $\mathrm{DO}_{\text {DEN }}$ from 0.49 to $0.30 \mathrm{mgO}_{2} \mathrm{~L}^{-1}$. Therefore, the 


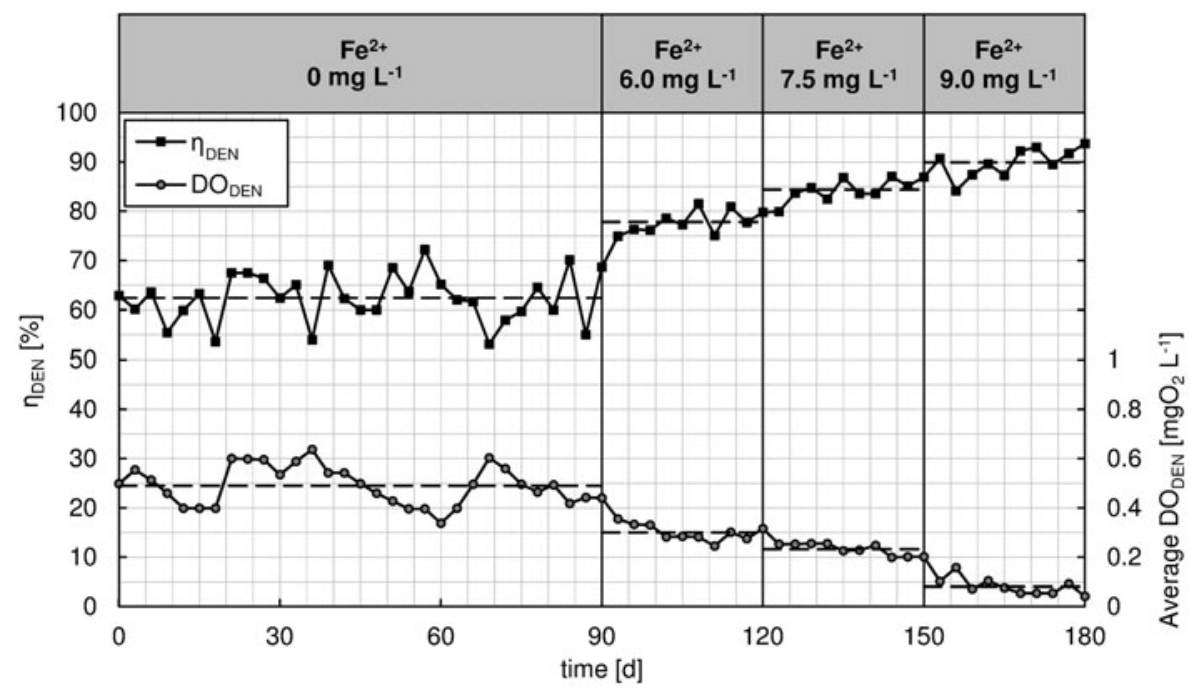

Fig. 3. Denitrification removal efficiency $\left(\eta_{\mathrm{DEN}}\right)$ as function of the average DO content in the denitrification reactor (average $\mathrm{DO}_{\mathrm{DEN}}$ ) during the four steps of the experimental period on the pilot plant. Dotted lines represent the mean values of $\eta_{\mathrm{DEN}}$ and $\mathrm{DO}_{\mathrm{DEN}}$ in each experimental step.

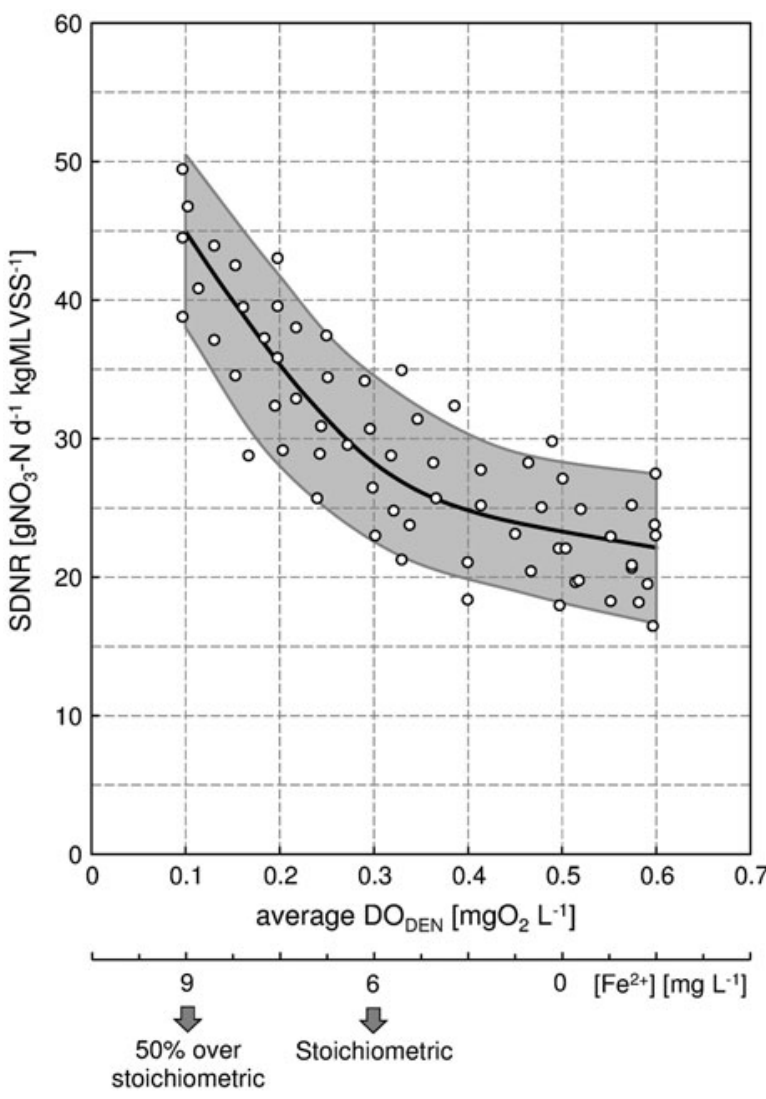

Fig. 4. SDNR as function of the average DO in the anoxic pre-denitrification tank (average $\mathrm{DO}_{\mathrm{DEN}}$ ) at $\mathrm{F}: \mathrm{M}_{\mathrm{DEN}}=0.3$ $\operatorname{kgBOD}_{5} \mathrm{kgMLVSS}^{-1} \mathrm{~d}^{-1}$ (temperature $T=18^{\circ} \mathrm{C}$ ). The additional $\mathrm{x}$-axis shows the concentration of the $\mathrm{Fe}^{2+}$ dosage. The continuous line and the shaded area represent the mean value and the $95 \%$ confidence limit, respectively. results confirmed that the addition of $\mathrm{Fe}(\mathrm{II})$ ions in the denitrification stage proves to be very efficient in controlling the DO content. Moreover, Fe(II), once oxidized to $\mathrm{Fe}(\mathrm{III})$, also determined the phosphorus removal through the precipitation of ferric orthophosphate.

Fig. 4 shows the SDNR as function of the $\mathrm{DO}_{\mathrm{DEN}}$.

SDNR shows a strong dependence from DO concentration in the range $0.08-0.3 \mathrm{mgO}_{2} \mathrm{~L}^{-1}$, dropping almost linearly from 45 to $27.5 \mathrm{gNO}_{3^{-}}$ $\mathrm{N} \mathrm{d}^{-1} \mathrm{kgMLVSS}^{-1}$. It is worth to note that such results were obtained with decreasing quantities of $\mathrm{Fe}^{2+}$ ions (Fig. 4). At $\mathrm{DO}_{\mathrm{DEN}}$ concentration higher than $0.3 \mathrm{mg} \mathrm{L}^{-1}\left(\mathrm{Fe}^{2+}\right.$ dosage: $0 \%$ over the stoichiometric for $P_{\text {tot }}$ removal) the influence of DO on SDNR can be considered not so important. Therefore, a good target for plant design operation seems to be an average DO concentration lower than $0.2 \mathrm{mgO}_{2} \mathrm{~L}^{-1}$, which corresponds to a SDNR at $18^{\circ} \mathrm{C}$ equal to about $35 \mathrm{gNO}_{3^{-}}$ $\mathrm{N} \mathrm{d}^{-1} \mathrm{kgMLVSS}^{-1}$ and a $\mathrm{Fe}^{2+}$ dosage of $25 \%$ over the stoichiometric for $\mathrm{P}_{\text {tot }}$ removal. Such conditions allow to achieve an average denitrification efficiency equals about $84 \%$ (Fig. 3).

\section{Conclusions}

The presence of DO in the biological denitrification tanks represents a serious limiting factor for the kinetics of the dissimilative reaction and, as a consequence, for the process efficiency. Literature indicates a reduc-

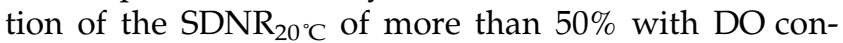
centration higher than $0.3 \mathrm{mgO}_{2} \mathrm{~L}^{-1}$. The experimental 
tests carried out on the pilot plant confirmed that the addition of ferrous ions in the denitrification stage proved to be very efficient in controlling the DO content, as it easily oxidizes the ferric ion. The dosage of $6 \mathrm{mgFe}^{2+} \mathrm{L}^{-1}$ is able to lower the mean DO concentration from 0.45 to $0.28 \mathrm{mgO}_{2} \mathrm{~L}^{-1}$ improving the denitrification efficiency from 64.8 to $77 \%$. The efficiency was further increased to $84 \%$ with $7.5 \mathrm{mgFe}^{2+} \mathrm{L}^{-1}$ (average DO in denitrification: $0.22 \mathrm{mgO}_{2} \mathrm{~L}^{-1}$ ) and up to $89 \%$ with $9 \mathrm{mg} \mathrm{Fe}^{2+} \mathrm{L}^{-1}$ (average DO in denitrification: $0.08 \mathrm{mgO}_{2} \mathrm{~L}^{-1}$ ). The results also highlighted the strong influence of $\mathrm{DO}$ (as a consequence of $\mathrm{Fe}^{2+}$ dosing) on the SDNR. In particular, SDNR shows a very pronounced reduction with $\mathrm{DO}$ concentration in the range of $0.05-0.3 \mathrm{mgO}_{2} \mathrm{~L}^{-1}$, while it tends to decrease much more slowly at $\mathrm{DO}$ values higher than $0.3 \mathrm{mgO}_{2} \mathrm{~L}^{-1}$. Therefore, in order to optimize the design of the denitrification stage as well as to achieve high operation efficiencies, average DO values lower than $0.2 \mathrm{mg} \mathrm{L}^{-1}$ could be suggested as the ideal value.

\section{References}

[1] US-EPA, Process Design Manual for Nitrogen Control; US-EPA, Water Resource Center, Jefferson, MO, 1975.

[2] E. De Fraja Frangipane, R. Cossu, G. Urbini, Modern trend in plant design for the removal of nutritive substances from sewage. Proceedings of the 2nd Int. Symposium on advanced wastewater treatment, Krakow, PL, 1978 (Wysokoefektywne Metody Oczyszczania Sciekow).

[3] M.H. Christensen, P.A. Harremoes, Literature review of biological denitrification of sewage, in: Proceedings of the International nitrogen as a Water Pollutant, Copenhagen, DK, August 18-20, 1975.

[4] M.H. Christensen, P.A. Harremoes, Nitrification and denitrification in wastewater treatment, in: R. Mitchell, (Ed.), Water Pollution Microbiology, vol. 2, John Wiley \& Sons, New York, NY, 1978, pp. 391-414.

[5] P.M. Sutton, K.L. Murphy, B.E. Jank, Nitrogen control: A basis for design with activated sludge systems, in: Proceedings of the International nitrogen as a Water Pollutant, Copenhagen, DK, August 18-20, 1975.

[6] V. Torretta, M. Ragazzi, E. Trulli, G. De Feo, G. Urbini, M. Raboni, E.C. Rada, Assessment of biological kinetics in a conventional municipal WWTP by means of the oxygen uptake rate method, Sustainability 6 (2014) 1833-1847.

[7] J.L. Barnard, Biological denitrification, Water Pollut. Control 74 (1975) 178-186.

[8] R. Vismara, Biological Treatment: Theory and Processes, third ed., Hoepli, Milano, 1998 (in Italian).

[9] G.A. Ekama, G.V.R. Marais, I.P. Siebritz, A.R. Pitman, G.F.P. Keay, L. Buchan, A. Gerber, M. Smollen, Theory, Design and Operation of Nutrient Removal Activated Sludge Processes, Water Research Commission (WRC), Pretoria, South Africa, 1984.

[10] G.A. Ekama, M.C. Wentzel, Denitrification kinetics in biological $\mathrm{n}$ and $\mathrm{p}$ removal activated sludge systems treating municipal wastewaters, Water Sci. Technol. 39 (6) (1999) 69-77.

[11] G.A. Ekama, Biological nutrient removal, in: P. Wilderer (Ed.), Treatise on Water Science - Volume 4: Water Quality Engineering, Elsevier, Amsterdam, 2011, pp. 409-526.

[12] G. Tchobanogolous, F.L. Burton, H.D. Stensel, Wastewater Engineering: Treatment and Reuse, fourth ed., McGraw-Hill, New York, NY, 2003.

[13] M. Raboni, V. Torretta, G. Urbini, Influence of strong diurnal variations in sewage quality on the performance of biological denitrification in small community wastewater treatment plants (WWTPs), Sustainability 5 (2013) 3679-3689.

[14] M. Raboni, V. Torretta, P. Viotti, G. Urbini, Pilot experimentation with complete mixing anoxic reactors to improve sewage denitrification in treatment plants in small communities, Sustainability 6 (2014) 112-122.

[15] M. Raboni, R. Gavasci, P. Viotti, Influence of the denitrification reactor Retention Time Distribution (RTD) on the dissolved oxygen control and the nitrogen removal efficiency, Water Sci. Technol. 72 (2015) 45-51.

[16] US-EPA, Nutrient Control Design Manual—State of Technology Review Report, US-EPA, Watertown, MA, 2009 (US-EPA publication; no. EPA/600/R-09/012).

[17] US-EPA, Nutrient control design manual, US-EPA, Watertown, MA, 2010 (US-EPA publication; EPA/ 600/R-10/100).

[18] R.N. Dawson, K.L. Murphy, The temperature dependency of biological denitrification, Water Res. 6 (1) (1972) 71-83.

[19] J. Oh, J.A. Silverstein, Oxygen inhibition of activated sludge denitrification, Water Res. 33(8) (1999) 1925-1937.

[20] B.G. Plósz, A. Jobbágy, C.P. Grady Jr., Factors influencing deterioration of denitrification by oxygen entering an anoxic reactor through the surface, Water Res. 37(4) (2003) 853-863.

[21] K.A. Badstreet, G.R. Jhonson, Study of critical operational parameters for nitrogen reduction at municipal wastewater treatment plant, in: Proceedings of Water Environment Federation 67th Annual Conference \& Exposition, Chicago, IL, October 15-19th, 1994.

[22] A. Luciano, P. Viotti, G. Mancini, V. Torretta, An integrated wastewater treatment system using a BAS reactor with biomass attached to tubular supports, J. Environ. Manage. 113 (2012) 51-60.

[23] P. Viotti, A. Luciano, G. Mancini, V. Torretta, A wastewater treatment using a biofilm airlift suspension reactor with biomass attached to supports: A numerical model, Int. J. Environ. Sci. Technol. 11(3) (2014) 571-588.

[24] J. Wan, M. Sperandio, Possible role of denitrification on aerobic granular sludge formation insequencing batch reactor, Chemosphere 75 (2009) 220-227.

[25] C.R. Burdick, D.R. Refling, H.D. Stensel, Advanced Biological treatment to achieve nutrient removal, J. Water Pollut. Control Fed. 54(7) (1982) 1078-1086.

[26] US-EPA, Nitrogen Control-Manual, US-EPA Office of Research and Development, Washington, DC, 1993 (US-EPA publication: EPA/625/R-93/010). 
[27] M. Henze, Capabilities of nitrogen removal process from wastewater, Water Sci. Technol. 23(4-6) (1991) 669-679.

[28] M. Raboni, V. Torretta, P. Viotti, G. Urbini, Calculating specific denitrification rates in pre-denitrification by assessing the influence of dissolved oxygen, sludge loading and mixed-liquor recycle, Environ. Technol. 35(20) (2014) 2582-2588.

[29] W. Stumm, G.F. Lee, Oxygenation of ferrous iron, Ind. Eng. Chem. 53(2) (1961) 143-146.

[30] H. Tamura, K. Goto, M. Nagayama, Effect of anions on the oxygenation of ferrous ion in neutral solutions, J. Inorg. Nucl. Chem. 38(1) (1976) 113-117.

[31] W. Sung, J.J. Morgan, Kinetics and product of ferrous iron oxygenation in aqueous systems, Environ. Sci. Technol. 14 (1980) 561-568.
[32] W. Davison, G. Seed, The kinetics of the oxidation of ferrous iron in synthetic and natural waters, Geochim. Cosmochim. Acta 47 (1983) 67-79.

[33] F.J. Millero, S. Sotolongo, M. Izaguirre, The oxidation kinetics of $\mathrm{Fe}(\mathrm{II})$ in seawater, Geochim. Cosmochim. Acta 51 (1987) 793-801.

[34] K.R. Applin, N. Zhao, The kinetics of Fe(II) oxidation and well screen incrustation, Ground Water 27(2) (1989) 168-174.

[35] J.L. Nielsen, P.H. Nielsen, Microbial nitrate-dependent oxidation of ferrous iron in activated sludge, Environ. Sci. Technol. 32(22) (1998) 3556-3561.

[36] Analytical Methods for Water, APAT and IRSA-CNR (Italian National Research Center), Rome, IT, 2003. Available from: <http://www.irsa.cnr.it/ShPage.php? lang=it\&pag=method $>$. 